\title{
Business Studies Academic Performance Differences of Secondary School Juniors in Akwa Ibom State of Nigeria
}

\author{
Udoukpong, Bassey E. \\ Department of Educational Foundations, Guidance and Counselling \\ University of Uyo, Uyo, Nigeria
}

Emah, Ime E.

Department of Curriculum Studies, Educational Management and Planning

University of Uyo, Uyo, Nigeria

Umoren, Shirley E.

Government Technical College, Uyo, Nigeria

Received: December 9, $2011 \quad$ Accepted: December 12, $2011 \quad$ Published: April 1, 2012
doi:10.5539/ies.v5n2p35

\begin{abstract}
The research examined the differences in the academic performance in Business Studies of a sampled secondary school junior students in Akwa Ibom State of Nigeria. A sample of 290 (138 male and 152 female) Junior Secondary Three $\left(9^{\text {th }}\right.$ grade) students was surveyed. The students' variables' being examined vis-à-vis academic performance in Business Studies were: 1) gender and 2) self-concept. Students' academic performance in Business Studies differed significantly on the basis of gender and self-concept. Implications for students' personal variables considerations in the teaching-learning of Business Studies are suggested.
\end{abstract}

Keywords: Business studies, Gender, Self-concept, Academic performance

\section{Introduction}

In most countries as in Nigeria, curriculum is developed to meet the national goals and objectives in the various fields and stages of manpower needs and development. It is therefore pertinent to observe that the introduction of the 6-3-3-4 system currently referred to as the 9-3-4 (9-Year Basic Education: Primary 1 to Junior Secondary 3; 3-Year Senior Secondary Education and 4-Year Tertiary Education) educational system in Nigeria had the goals and the operation of the system in line with the country's national education goals as highlighted in the National Policy on Education. The Nigerian national educational goals which are derived from the country's philosophy and goals include, "the acquisition of appropriate skills and the development of mental, physical and social abilities and competencies as equipment for the individual to live in and contribute to the development of the society" (Federal Republic of Nigeria (FRN), 2004:8).

In order to realize fully the potentials of the contributions of education to the achievement of the national educational goals, emphasis is placed on the broad goals of secondary education which aim at preparing individuals for "useful living within the society and for higher education" (FRN, 2004:18). More specifically, in the junior secondary the curriculum provides for both the academic and pre-vocational subjects. The focus of the secondary education at the junior level targets the realization of the following goals, "to offer diversified curriculum to cater for the differences in talents, opportunities and future roles; to provide trained manpower in the applied sciences, technology and commerce at sub-professional grades, and to provide technical knowledge and vocational skills necessary for agricultural, industrial, commercial and economic development" (FRN, 2004:17-19). These goal statements had guided the efforts toward the developing of new curricula for the junior secondary education in the pre-vocational electives which include, "Agriculture, Business Studies, Home Economics, Computer Education, Fine Arts and Music" (FRN, 2004:20).

Business Studies is taught as one of the basic subjects that will enable students acquire further skills which are common and fundamental to all personal and occupational activities (Inyang, 1998). Business activity affects the 
daily lives of all Nigerians as they work, spend, save, invest, travel and play. It influences jobs, incomes and opportunities for personal enterprise. Business has significant effect on the standard of living and quality of life of people, and on the environment in which they live and which future generations will inherit (Ekanem, 2008). Eventually, all students will encounter the world of business, whether they work in urban or rural areas. They must be prepared to engage in business activity with confidence and competence.

A quantitative synthesis of over 3,000 students showed that nine educational variables are effective in fostering students' learning and performance. These are ability, development, motivation, attitude, quality of instruction and environmental factors which include the home, classroom, peer group and the mass media (Fraser, Walberg, Welch and Hattie, 1987). Academic performance of junior secondary students in Business Studies can be differentiated by many factors as students have many responsibilities with regard to their learning. However, taking responsibility for their own progress and learning is an important part of education for all students, regardless of their circumstances, hence this research study.

\subsection{Gender Differences in Academic Performance}

In their classic volume on gender differences (Maccoby and Jacklin, 1974) cited in Wigfield, Battle, Keller and Eccles (2000) concluded that there are gender differences favouring girls in verbal abilities and performance, favouring boys in mathematics ability and performance (particularly in problem solving rather than computation, during adolescence) as well as in spatial ability. In their review of gender differences in these areas, Hyde and Linn (1988) and Linn and Hyde (1989) argued that many of these differences have decreased to the point where they are negligible. However, in the mathematics ability area boys continue to be more highly represented in the highest performing groups of children and adolescents (Roger, Tronsky and Chan, 1999). In general, girls earn higher grades than boys across the school years even in mathematics and science despite not doing well on tests of mathematical ability during adolescence (Roger, Tronsky and Chan, 1999).

Although the overall mathematics ability differences favour boys in certain mathematical areas such as counting and computation, girls do better especially in elementary school. Gender differences appear to have decreased over the last 25 years (Ruble and Martin, 1998). Girls continue to outperform boys in school if grades are the indicator of performance (Wigfield, Battle, Keller and Eccles, 2000).

In earlier work, gender differences in the value of mathematics did not emerge until high school (Eccles, 1984); in recent study, high school girls value mathematics equally (Jacobs, Lanza, Osgood, Eccles and Wigfield, 2002). The fact that adolescent girls have less positive view of their mathematics ability is problematic because these differences likely contribute to girls' lower probability of taking optional advanced level mathematics courses and physical science and entering mathematics-related scientific and engineering fields, thus contributing to gender-differentiated cognitive outcomes (Eccles, 1994).

Although school subjects no longer appear to be clearly gender stereotyped, boys and girls do vary in their interest in different subject areas. Wigfield, Eccles, Yoon, Freedman-Doan and Blumenfeld (1997) in their studies found that boys and girls differed in their interest in reading, music and sport in gender stereotypic ways. However, boys' and girls' interest in mathematics did not differ during elementary school (Folling-Albers and Hartinger, 1998). During secondary school boys appear to be more interested in mathematics than girls. Similar findings have been reported for science and other technical fields (Gardner, 1998). Individuals' interests play strong roles in their choices of which activities to pursue, both in and out of school. The differences in patterns of interest potentially are crucial for understanding differences in cognitive performance (Wigfield, Battle, Keller and Eccles, 2000).

One generalization about gender differences in academic achievement is that males as a whole in their cognitive abilities appear to be much more variable than females. There are more males at the very high and low ends than there are females (Hedges and Nowell, 1995). Females usually score higher on written measures than they do on multiple choice questions and the reverse tends to be true for males (Hedges and Nowell, 1995). In a study of students' academic performance in Business Studies by gender, Ekanem (2008) used a total of 600 junior secondary students (300 males and 300 females). The finding of the study indicated that the performance mean score for the males was 25.07 as against the female performance mean score of 25.87 . The calculated t-test value showed no significant difference between the two mean scores.

Many authors have pointed out that drawing conclusions about gender differences in academic performance should be done carefully (Eisenberg, Martin and Fabes, 1996; Ruble and Martin, 1998). Although differences are often observed in academic performance of boys and girls, in general, they tend to be relatively small in terms of the amount of variance explained (Marsh, 1989). Thus, there often is substantial overlap between boys and girls in many different variables measured in studies of gender differences. Individual differences within groups of males and females often are stronger than differences between the two groups (Wigfield, Battle, Keller and Eccles, 2000). 
There are few direct available research studies on Business Studies. All the works reviewed in this section are related to Business Studies through its integrated components of typewriting, shorthand, commerce, office practice and bookkeeping. Bookkeeping and commerce have much elements of accounting and mathematics while shorthand, office practice and typewriting are related to reading, verbal and technical subjects, hence, the reviewed studies are applicable to the current research study. Based on the above reviewed literature, the present study hypothesizes that junior secondary students' academic performance in Business Studies will not be significantly differentiated on the basis of gender.

\subsection{Self-Concept Differences in Academic Performance}

Sanchez and Roda (2008) studied the relationship between self-concept and academic achievement of primary school pupils. A total of 245 pupils participated in the study, all of them in sixth year Primary Education. One of the hypotheses expected that specific factors of self-concept in mathematics and reading would be more closely associated to specific areas of learning. The result on the hypothesis showed that self-concept in mathematics (cognitive and affective dimensions) had very similar levels of association to the measures of achievement. The same was observed of self-concept in reading. It seems, then, that the subjects' self-concept, be it in reading or in mathematics, is associated to a similar degree with academic performance that subjects obtained in the area of language arts, mathematics, and in general.

Alexander (1997) studied the relationship between academic performance and intelligence, learning strategies and academic performance. Data from the study showed a high degree of positive, significant association between global self-assessment and academic self-concept, as well as between academic performance and academic self-concept. Another study similar to the previous one reported that academic self-concept proved itself favourably associated with academic performance (Castor, 1997).

Villarroel (2001) reports several revealing results regarding self-concept with the findings which showed: (1) a linear association between self-concept and academic performance; (2) reciprocal influences between teachers' expectations, students' academic performance and students' self-concept; and (3) effects of students' academic performance on teachers' perception. Studies by Acosta (2001) also stand out, where the researcher examined the relationship between school climate, academic self-concept, and academic performance. The findings supported that multiple regression analyses gave indices where the predicting variables explained as much as $18 \%$ of the variance in academic achievement, though only the variance explained by self-concept was statistically significant. Boulter (2002) used self-concept as a predictor of academic performance.

Gonzalez-Pienda et al. (2002) reported from the International Conference on Motivation: $6^{\text {th }}$ Workshop on Achievement and Task Motivation held in Greece that results presented from several investigations where relationships between self-concept and academic achievement was measured by a longitudinal strategy (with an interval of one year between the pretest and the posttest) supported reciprocal relationship. Not only so, but results indicated that self-concept was the immediate cause of academic achievement, considering that the influence or relevance of achievement would be at the base of long-term relationship. They therefore considered academic self-concept as a powerful motivating force that responds to the students' immediate achievement.

A primary psychological mediator of the relationship between students' engagement and educational context is the degree to which students feel competent and confident of their ability to be successful in completing educational tasks. Students who are convinced that they lack the ability to succeed or control the outcome of their educational experience will not make an effort to engage or excel in school related work (Skinner, Wellborn and Connell, 1990; Skinner, Zimmer-Gembeck and Connell, 1998). To become successful, students need to know what it takes to succeed and believe they can succeed, given what they know.

High, clear and consistent expectations support students' self-confidence, their belief that their efforts will lead to success and their engagement in school (Gambone, Klem, Summers and Akey, 2004). To motivate students, however, standards and expectations must be clear and genuinely achieveable (Gambone, Klem, Summers and Akey, 2004). Students are most likely to be academically engaged when goals set are set at an appropriate level - that is, when they both challenge students and allow them to experience a sense of competence and accomplishment.

It is important that what research had shown about the relations of self-concept to achievement has been reviewed. Although the causal direction in this relationship had long been debated, and likely is reciprocal by middle school (Marsh and Yeung, 1997), it has been clearly documented. When children have positive self-concept in a given area, they also achieve better, and vice versa.

On the basis of the above literature review, it is appropriate to hypothesize that primarily among other socio-psychological variables, junior secondary students' academic self-concept, non-academic self-concept and the 
total self-concept sub-variables put together would be responsible for differences in their academic achievement in Business Studies.

\subsection{Purpose of the Study}

The study explored junior secondary students' personal variables typified by gender and self-concept vis-à-vis academic performance in Business Studies. It was assumed that understanding the role of the identified personal variables in the academic achievement differences of students in Business Studies can lead to or even create deeper insight into how such variables could be manipulated to improve academic performance in schools. The findings of the study would be useful to teachers by helping them bring enthusiasm and varied instructional strategies into the classroom to address the different needs of students thus ensure sound and productive learning opportunities for every learner.

\subsection{Importance of the Research Study}

The findings of this study would be important to teachers and teacher educators who need to understand the factors which may affect students' academic performance in school subjects including Business Studies. It will help them to work toward providing experiences that are motivating to students against the backdrop of gender and self-concept differences. This will thereby contribute to students' interest, self-confidence and effective learning as individual differences are considered in the course and planning and delivery of academic instructions.

Webster and Fisher (2000) indicated that there is a link between personal variables and academic achievement in school. The findings of this study may have important implications for understanding the role of gender and self-concept differences in students academic performance in Business Studies as a subject which provides rich opportunities for real-world experiences. They would be of immense value to the school counselors as they offer career counseling, vocational guidance and occupational information to students.

The findings also make clear that understanding the role of gender and self-concept differences in academic achievement would lead to or even create deeper insight into how the variables could be manipulated to improve academic achievement. Identify variables that could explain differences in junior secondary students' academic performance in Business Studies can aid experts who may wish to develop a curriculum on entrepreneurial studies for schools.

The findings of this research study suggest that teachers should be supportive of students by providing clear and high expectations about behaviour as the key to the development of both students' commitment to studies and perceived competence. The earlier schools and teachers begin to build students' confidence in their ability to do well, the better off students will be. Because students' perceptions of their capability for success are key to their commitment to school and learning, schools should be designed to enhance students' feelings of accomplishment.

It is believed that the findings of this study have brought to the fore the need to re-assess the Business Studies curriculum and other pre-vocational subjects taught in junior secondary schools in Nigeria taking into consideration the learners' personal variables. Such a re-assessment may have implication for students who may wish to change their perception toward Business Studies education and the teachers, their instructional strategies. But without empirical investigation of students academic performance in Business Studies as may be differentiated by gender and self-concept, there exists little basis for teachers to develop appropriate instructional strategies to help students achieve the curriculum expectations. Teachers would have great reluctance to change the status quo of their teaching without adequate proof of need. It was against the background of helping teachers bring enthusiasm and varied teaching strategies into the classroom, addressing different student needs and ensuring sound learning opportunities for every student that the study identified gender and self-concept variables vis-à-vis academic performance in Business Studies for investigation.

\section{Methodology}

\subsection{Subjects}

The participants in the study consisted of 290 (138 male and 152 female) Junior Secondary Three (9 $9^{\text {th }}$ grade) students drawn from 8 public secondary schools in Uyo Local Government Area of Akwa Ibom State, Nigeria. Stratified random sampling and proportional sampling techniques were employed to obtain the sample for the study. All the 290 participants completed the Personal Variable Rating Scale which composed of 15 Likert-type items on the variable of self-concept. The possible responses to the rating scale ranged from 5 (strongly agree) to 1 (strongly disagree). However, the rating scores were reversed for negative items. The neutral score was 3 , thus, the composite score for the personal variable rating (self-concept) ranged between 75 (maximum) and 15 (minimum). A positive direction toward self-concept was placed between 46 and 75 while negative disposition was between 15 and 45 . Frequency count of subjects was employed in the distribution of subjects into the gender group. 
All the students who participated in the study offered Business Studies as one of the pre-vocational subjects in the junior secondary curriculum; their age averaged 14 years.

\subsection{Hypotheses}

The study tested the following null hypotheses at the 0.05 level of significance:

1) There is no significant difference in the academic performance in Business Studies of junior secondary students based on gender.

2) There is no significant difference in the academic performance in Business Studies of junior secondary students based on self-concept.

\subsection{Instrumentation}

The research instruments consisted of the "Personal Variable Rating Scale" and the "Business Studies Achievement Test".

\subsubsection{Personal Variable Rating Scale}

The rating scale contained 15 items of a 5-point Likert scale with declarative statements on self-concept issues of respondents. Content validity was established by a panel of experts consisting of university faculty members in the Department of Guidance and Counselling. Five options were available for rating ranging from "strongly agree" (5 points) to "strongly disagree" (1 point). Pilot testing for suitability and reliability was carried out with junior secondary students in schools not included in the sample. The Spearman-Brown split-half formula resulted in reliability coefficient of 0.76 .

\subsubsection{Business Studies Achievement Test}

The 50-item multiple choice questions to assess the junior secondary students' academic achievement in Business Studies was adapted from the Junior Secondary School Certificate Examination questions of the 2005/06 through 2009/10 academic sessions. Questions were selected for each component of Business Studies through the item analysis technique. Content validity was established by a panel of experts consisting of university faculty members in the Department of Vocational Education and secondary school Business Studies educators. Pilot testing for suitability and reliability was conducted with junior secondary students in schools not included in the sample. The test-retest reliability coefficient of the Business Studies achievement test was 0.84 .

\subsection{Data Collection}

Data were collected with the assistance of subject masters in the schools involved in the study. A duration of 15 minutes was allowed for the completion of the self-concept rating scale while 60 minutes was allowed for writing answers to the performance test on Business Studies.

\subsection{Data Analysis}

Data were described using means and standard deviations. The independent t-test was used to establish the significant differences in students' academic performance in Business Studies based on the variables of gender and self-concept.

\section{Results}

\subsection{Gender of Students}

Data in Table 1 indicate that there was a significant difference in the academic performance mean scores of junior secondary students in Business Studies based on gender $(t=3.99, \mathrm{p}<0.05)$. The female students had a higher academic performance mean score in Business Studies than the male counterparts (59.59 vs. 52.93).

\subsection{Self-Concept of Students}

Data reporting junior secondary students' academic performance in Business Studies as differentiated by self-concept are in Table 2. The t-test analysis showed a significant difference in the students' academic performance in Business Studies based on self-concept $(t=3.22, p<0.05)$. The high self-concept perceived students performed better than the low self-concept perceived students (57.86 vs. 50.67$)$.

\subsection{Study Limitations}

The findings of this study suggest interesting differences among students' academic achievement in Business Studies in respect of gender and self-concept and also provide some evidence about the nature of linkage between the two constructs. However, it is important to note that the study has some limitations associated with the sample of students in the analysis, the data collection methods and the overall study design approach. 
The sample for the study was drawn from a set of students primarily of different family background characteristics. The findings may not generalize to other group of students as the research base was mostly on information from the respondents who fell short of the random assignment design that some researchers believe is necessary to drawn causal conclusions.

The data used in the analyses were based mainly on students' self-reports (with exception of academic achievement data). They did not involve teachers' reports or direct classroom observations. Without additional data, it is difficult to equate students' personal judgment with potential behaviour using questionnaire, hence, the validity of the students' responses becomes susceptible.

Finally, the approaches to the data collection and the data analyses here cannot yield definitive conclusions. While the ex-post facto design allows for testing hypotheses based on constructs of the independent variable (gender and self-concept) which had already occurred and are studied retrospectively, only with caution should the findings be interpreted as causal. It is possible for a condition to preceed an outcome without causing the outcome (Akey, 2006).

\section{Discussion of Results}

\subsection{Gender and Academic Performance in Business Studies}

The result of the data analysis revealed that gender has a role to play in differentiating the academic performance of junior secondary students in Business Studies. This finding contradicts an earlier finding in the study by Ekanem (2008) which found no significant difference in students' academic performance in Business studies based on gender. The finding of significant difference in students' academic performance in favour of the female students is supported by the findings in studies by Royer, Tronsky and Chan (1999), and Wigfield, Battle, Keller and Eccles (2000) whose studies found girls earning higher grades than boys across school years.

The finding of this study could be assumed to indicate that the male students regard Business Studies as a stereotyped feminine subject which has linkage with feminine occupation such as secretarial, waitress and clerical work. Hence, not motivated to attach much importance to learning it. According to Jersild, Brook and Brook (1978) more women are employed in clerical job than in any category. Although school subjects no longer appear to be clearly gender stereotyped, boys and girls do vary in their interest in different subject areas (Wigfield, Eccles, Yoon, Harold and Blumenfeld, 1997).

The higher performance of female students in Business Studies may not be unconnected with the belief in the utility value of the subject. According to Deci and Ryan (1985) "a task can have positive value to a person because it facilitates important future goals, even if the person is not interested in the task for its own sake" (p.7). In one sense, therefore, the utility value of Business Studies as it relates to current and future goals, such as career goals might have served as the extrinsic reason for the girls to outperform the boys.

What might be more important for understanding gender differences in performance in Business Studies may not be course taking per se but what occurs in the classroom. Casserly (1980) and Eccles (1987) observed that there are sex differences in children's preference for different types of instructional practices, which likely interact with subject area to produce sex differences in interest in different subject areas. According to Wigfield, Battle, Keller and Eccles (2000) females appear to respond more positively to subjects if taught in cooperative or individualized manner rather than a competitive manner; if it is taught from an applied or person-centred perspective rather than a theoretical or abstract perspective and if taught using hands-on approach rather than a "book learning" approach. Such preferred conceptual perspectives of instruction are supposed to be associated with an effective Business Studies classroom. Therefore the higher performance mean score in Business Studies by the female students can further be attributed to the teaching style, the instructional focus and females' value goals, motivational orientation and the learning styles which the teachers might have brought to bear in the course of implementing the Business Studies curriculum as a pre-vocational subject.

\subsection{Self-Concept and Academic Performance in Business Studies}

The difference in junior secondary students' academic performance in Business Studies based on self-concept showed that the high self-concept perceived students performed better in the subject than their low self-concept perceived counterparts. A possible explanation to this finding is that a child's positive self-concept is perhaps the basis for his/her educational progress and achievement. According to Sanchez and Roda (2008) "levels of self-concept determine the degree of academic achievement" (p.49). The students' differential academic performance in Business Studies based on self-concept can be assumed to be a matter of personality factor. Self-concept constitutes a psychological dimension of how an individual evaluates self in terms of what he/she can do or achieve. Marsh and Yeung (1997) had clearly documented that "when children have positive self-concept in a given area, they also achieve better and vice versa. In this study, it could be assumed that students who were 
convinced that they lacked the ability to succeed failed to make effort to perform well in the Business Studies achievement task. This assumption is corroborated by Skinner, Zimmer-Gembeck and Connell (1998) who observed that "students who are convinced that they lack the ability to succeed will not make an effort to engage or excel in school related work" (p.98).

Several studies ratify the result of the study. Alexander (1997) studied the relationship between academic performance and self-concept. Data from the study showed a high degree of positive, significant association between general self-assessment and academic self-concept, as well as between academic performance and academic self-concept. In like manner, Castor (1997) in a study found that academic self-concept proved itself favourably associated with academic performance. Hence, the differential academic performance in Business Studies by junior secondary students in this study could be explained to the psychological mediator of the relationship between students' engagement and educational context. That is, the degree to which students feel competent and confident in their ability to be successful has impact on school academic performance.

\section{Conclusions and Implications}

On the basis of the research results and finding in this study, it can be concluded that students' gender and self-concept do contribute to academic achievement in school learning, notably Business Studies. Business Studies learning has a lot to do with entrepreneurship which is strongly advocated to be taught in schools.

Male and female students as well as high and low self-concept perceived students differed significantly in their academic performance as regards Business Studies subject. It is therefore recommended that junior secondary students should be encouraged to take Business Studies as an important school subject against the backdrop that business activity affects daily lives of all citizens as they work, spend, save, invest, travel and play. Such encouragement should come by way of high-quality classroom instruction drawn on students' pre-existing knowledge, culture and real-world experiences as well as explicit rewards.

Adequate and sufficient attention should be given to learners' self-concept and self-esteem. This should be pursued by guidance and counseling services unit of schools to help students handle social, psychological, occupational and academic challenges meaningfully. Students should be helped to build self-confidence by creating notion of the capability to succeed in life through supportive network of relationships in the family and school personnel.

\subsection{Suggestions for Further Research}

In view of the academic performance results and the delimitation of this study to only eight public schools in Akwa Ibom State of Nigeria with a study sample of 290 participants only, suggestions for further research are hereby offered:

1) A replication of this study with a large study sample to cover other states in Nigeria would ascertain the general application of the findings and conclusions.

2) Understanding how students learn in the classroom could serve as the key factor for promoting academic success among students. Hence, research should be carried out on "Classroom climate, students' attitudes and behaviour and academic achievement" in any chosen area.

3) Educational psychology has been concerned with analyzing different types of relationships, both associative and predictive, that exist between self-concept and academic performance (Gonzalez-Pienda, Nunez, Gonzalez-Pumariega, Alvarez, Roces, Garcia, and Valle, 2002). It is therefore needful to continue to conduct research for more information on certain psychosocial, family - and school-related variables (parents' profession, parental influence, school experiences or peer group influence) and the development of gender stereotypic and self-concept.

4) Most learning situations encompass male and female students, hence, any exploration into "Gender differences in study habits, self-concept, career aspiration and career choice: Implications for cognitive development" would serve as a bolster for this study

\section{References}

Acosta, E. S. (2001). The Relationship Between School Climate, Academic Self-Concept, and Academic Achievement. Dissertation Abstracts International Section A: Humanities and Social Sciences, 65(5-A): 1717.

Affaires et Commerce (2006). The Ontario Curriculum: Business Studies. Ministry of Education. [Online] Available: http: //www.edu.gov.on-ca. (May 6, 2010).

Akey, T. M. (2006). School Context, Student Attitudes and Behaviours and Academic Achievement: An Exploratory Analysis. [Online] Available: www. Mdrc.org (May 6, 2010). 
Alexander, S. (1997). The Relationship of Self-Concept, IQ, Academic Performance, and Stressors to Coping Abilities for Urban African-American Gifted Students. Dissertation Abstracts International Section A: Humanities and Social Sciences, 58(5-A): 1575.

Boulter, L.T. (2002). Self-Concept as a Predictor of College Freshmen Academic Adjustment. College Student Journal, 36(2): 234-246.

Casserly, P. (1980). Women and mathematical mystique. Baltimore: John Hopkins University Press (pp 138-163).

Castor, S. E. (1977). Locus of Control and Self-Concept in Achieving and Underachieving Gifted Students. Dissertation Abstracts International: Section B: The Science and Engineering, 57 (10-B):6603.

Deci, E. L., \& Ryan, R. M. (1985). Intrinsic motivation and self-determination of human behavior. New Yo4rk: Plenum Press.

Eccles, J. S. (1984). Sex Differences in Achievement Patterns. In T. Sonderegger (Ed.), Nebraska symposium on motivation, 32:97-132. Lincoln, NE: University of Nebraska Press.

Eccles, J. S. (1987). Gender Roles and Women's Achievement-Related Decisions. Psychology of Women Quarterly, 11:135 - 172. http://dx.doi.org/10.1111/j.1471-6402.1987.tb00781.x

Eccles, J. S. (1994). Understanding Women's Educational and Occupational Choices: Applying the Eccles et al. Model of Achievement-Related Choices. Psychology of Women Quarterly, 18: 585-609. http://dx.doi.org/10.1111/j.1471-6402.1994.tb01049.x

Eisenberg, N. Martin, C. L., \& Fabes, R. A. (1996). Gender Development and Gender Effects. Handbook of educational psychology, pp. $358-396$.

Ekanem, G. E. (2008). Student characteristics and academic performance in Business Studies in Junior Secondary Schools in Akwa Ibom State, Nigeria. Unpublished M.Ed Dissertation, University of Uyo, Uyo.

Federal Republic of Nigeria (FRN) (2004). National Policy on education. Lagos: National Education Research and Development Council.

Folling-Albers, M., \& Hartinger, A. (1998). Interest in boys and girls in elementary school. Interest and Learning. Kiel, Germany: $\quad$ Institute for Science Education (pp. 175-183).

Fraser, B. J., Walberg, H. J., Welch, W.W., \& Hattie, J. A. (1987). Synthesis of Educational Productivity Research. Journal of Educational Research, 11(2): 147-252.

Gambone, M. A., Klem, A. M., Summers, J. A., \& Akey, T. A. (2004). Turning the tide: The achievements of the First Things First Education Reform in the Kansas City. Philadelphia: Youth Development Strategies Inc.

Gardner, P. L. (1998). The development of males' and females' interests in science and technology. Interest and Learning. Kiel, Germany: Institute for Science Education (pp. 41-57).

Gonzalez-Pienda, J. A., Nunez, J. C., Gonzalez-Pumariega, S. I., Alvarez, L., Roces, C., Garcoa. M., \& Valle, A. (2002). Self-Concept, Causal Attribution Process and Academic Goals in Children With and Without Disabilities. Psicothema, 12(4): 548-556.

Hedges, L., \& Nowell, A. (1995). Sex Differences in Mental Test Scores: Variability and Numbers of High-Scoring Individuals. Science, 9: 41-45. http://dx.doi.org/10.1126/science.7604277

Hyde, J. S., \& Linn, M. C. (1988). Gender Differences in Verbal Ability: A Meta-Analysis. Psychological Bulletin, 104: 53-69. http://dx.doi.org/10.1037/0033-2909.104.1.53

Jacobs, J. E., Lanza, S., Osgood, D. W., Eccles, J. S., \& Wigfield, A. (2002). Changes in Children's Self-Competence and Values: Gender and Domain Differences Across Grades One Through Twelve. Child Development, 73(2): 509-527. http://dx.doi.org/10.1111/1467-8624.00421

Linn, M. C., \& Hyde, J. S. (1989). Gender, Mathematics and Science. Educational Researcher, 18: 17-19; 22-27.

Maccoby, E. E., \& Jacklin, C. N. (1974). The psychology of sex differences. Standford, CA: Standford University Press (Chapter 2).

Marsh, H. W. (1989). Age and Sex Effects in Multiple Dimensions of Self-Concept: Preadolescence to Early Adulthood. Journal of Educational Psychology, 81: 417-430. http://dx.doi.org/10.1037/0022-0663.81.3.417

Marsh, H. W., \& Yeung, A. S. (1997). Causal effects of academic self-concept on academic achievement: Structural equation models of longitudinal data. Journal of Educational Psychology, 890:41-54. http://dx.doi.org/10.1037/0022-0663.89.1.41 
Royer, J. M., Tronsky, L. H., \& Chan, Y. (1999). Math-fact Retrieval as the Cognitive Mechanism Underlying Gender Differences in Math Test Performance. Contemporary Educational Psychology, 24:181-266. http://dx.doi.org/10.1006/ceps.1999.1004

Ruble, D. N., \& Martin, C. L. (1998). Gender development. In W. Damon (Series Ed.) and N. Eisenberg (Vol. Ed.), Handbook on Child Psychology (5 ${ }^{\text {th }}$ ed.), pp. 933-1016.

Sanchez, F. J. P., \& Roda, M. D. S. (2008). Relationship Between Self-Concept and Academic Achievement in Primary Students. Electronic Journal of Research in Educational Psychology and Psychopedagogy, 1(1): 95-120.

Skinner, E. A, Zimmer-Gembeck, M., \& Connell, J. P. (1998). Individual differences and the development of perceived control. Monographs of the Society for Research in Child Development, 62(2-3): 10220. http://dx.doi.org/10.1037/0022-0663.82.1.22

Skinner, E. A., Wellborn, J. G., \& Connell, J. P. (1990). What It Takes to Do Well in School and Whether I've Got It: A Process Model of Perceived Control and Children's Engagement and Achievement in School. Journal of Educational Psychology, 82: 22-32.

Villarroel, Y. A. (2001). Relationship Between Self-Concept and Academic Performance. Psicologia, 10(1): 3-18.

Webster, B. J., \& Fisher, D. L. (2000). Accounting for Variation in Science and Mathematics Achievement. Science Study, 5: 323-245.

Wigfield, A., Battle, A., Keller, L. B., \& Eccles, J. S. (2000). Sex differences in motivation, self-concept, career aspiration and career choice: Implication for cognitive development. In A. V. McGillicuddy-De Lisi \& R. De Lisi (Eds.), Biology, sociology and behavuiour: The development of sex differences in cognition. Greenwich, C.T.: Ablex (Chapter 5).

Wigfield, A., Eccles, J. S., Yoon, K. S., Harold, R. D., \& Blumenfeld, P. C. (1997). Changes in Children's Competence Beliefs and Subjective Task Values Across the Elementary School Years: A Three-Year Study. Journal of Education Psychology, 89:451-469. http://dx.doi.org/10.1037/0022-0663.89.3.451

Table 1. T-test analysis of junior secondary students' academic performance in Business Studies by gender

\begin{tabular}{|llllll|}
\hline Gender & $\mathrm{N}$ & Mean & SD & t-value \\
\hline Female & 138 & 52.93 & 14.71 & \\
& & & & $3.99 *$ \\
Female & 152 & 59.59 & 13.66 & \\
\hline
\end{tabular}

$* \mathrm{p}<0.05 \quad \mathrm{df}=288$

Table 2. T-test analysis of junior secondary students' academic performance in Business Studies by self-concept

\begin{tabular}{|lcccc|}
\hline Self -Concept & N & Mean & SD & t-value \\
\hline High & 232 & 57.86 & 13.94 & \\
& & & & $3.22^{*}$ \\
Female & 58 & 50.67 & 15.53 & \\
\hline
\end{tabular}

$* \mathrm{p}<0.05 \quad \mathrm{df}=288$ 